\title{
Cephalometry in 14-18 Years Old Girls and Boys of Shiraz-Iran High School
}

\author{
Cefalometría en Niñas y Niños de 14-18 Años de la Secundaria de Shiraz, Irán
}

\begin{abstract}
"Zahra Vojdani; "*Noghra Bahmanpour; ***:Shahla Momeni; ${ }^{* * * *}$ Atieh Vasaghi; ${ }^{* * * *}$ Azadeh Yazdizadeh; *****Amirali Karamifar;
\end{abstract} ${ }^{* * * * * *}$ Amirhosseine Najafifar; ${ }^{* * * * * *}$ Shahram Setoodehmaram $\&^{* * * * * * *}$ Ali Mokhtar

VOJDANI, Z.; BAHMANPOUR, S.; MOMENI, S.; VASAGHI, A.; YAZDIZADEH, A.; KARAMIFAR, A.; NAJAFIFAR, A.; SETOODEHMARAM, S. \& MOKHTAR, A. Cephalometry in 14-18 years old girls and boys of Shiraz-Iran high school. Int. J. Morphol., 27(1):101-104, 2009.

\begin{abstract}
SUMMARY: Cephalometry or skull measurement are used in pediatrics, forensic medicine, plastic surgery, oral surgery and diagnostic comprehension between patient and normal populations. Cephalic index is an important parameter for detecting the race and sex of an individual whose identity is unknown. The most important of cephalometric dimension are height and width of head which determine cephalic index. On the basis of cephalic index four head shapes are determined in international categories, that including dolichocephal, brachycephal, mesocephal and hyperbrachycephal. With noticing the lack of documented research about 14-18 years old girls and boys in this area, this study was planned for determining normal range of head shapes in 867girls and 960 boys in the age of 14-18 in fars-Iran. In regards of cephalic index our results showed that dominent type of head in girls was brachycephalic with $42.5 \%$ and in boys was hyperbrachycephalic with $34.3 \%$, rare type of head shape in girls was dolicocephalic with $4.80 \%$ and in boys was $7.5 \%$. There is significant difference between boys and girls cephalic index.
\end{abstract}

KEY WORDS: Cephalometry; Cephalic index; Student.

\section{INTRODUCTION}

Human physical variability had been a subject of interest for the scientists since a very long time. Anthropometry, the standardized scientific techniques of measuring human body was soon developed to make collection of data comparable (Eickstedt, 1926; Thurston, 1909).

Anthropometrics studies are conducted on the age, sex and racial/ethnic groups in certain geographical zones (Williams et al., 1995; del Sol, 2005; Shah \& Jadhav, 2004; Golalipour et al., 2007). The name of cephalometry is given to the morphological study of all the structures present in a human head (Grau et al., 2001).

The method currently availed craniofacial form include anthropometry, photogram entry, cephalometry, ultrasound, computed tomographic (CT) scanning magnetic imaging (MRI) and optical surface scanning (Grant \& Peter, 2003).
Arguably, cephalometry continues to be the most versatile technique in the investigation of the craniofacial skeleton because of its validity and practicality (Grant \& Peter). Comparison of the measurements with the standards for the same age, race, and sex is a valuable tool for diagnosis, treatment monitoring and prediction of orthodensy treatment results (Grau et al.).

The most important of cephalometric dimension are height and width of head that they used in cephalic index determination. On basis of cephalic index the head shapes classified to four international categories, that including dolichocephal, brachycephal, mesocephal and hyperbrachycephal (Williams et al.; del Sol). A few investigations carried out to determine the type of head shape in various ages in Iran and other countries Regading, the effect of racial, ethnic and geographical factors on head dimensions and lack of documented research about 14-18 years old girls and

\footnotetext{
Assistant Professor of Anatomy, Shiraz University of Medical Sciences, Shiraz, Iran.

** Professor of Anatomy, Shiraz University of Medical Sciences, Shiraz, Iran.

**** Associated Professor of Dentistry, Shiraz University of Medical Sciences, Shiraz, Iran.

**** Medical Student, Shiraz University of Medical Sciences, Shiraz, Iran.

****** Orthodontist students of Shiraz University of Medical Sciences, Shiraz, Iran.

${ }^{* * * * * *}$ Dentistry Students of Shiraz University of Medical Sciences, Shiraz, Iran.
} 
VOJDANI, Z.; BAHMANPOUR, S.; MOMENI, S.; VASAGHI, A.; YAZDIZADEH, A.; KARAMIFAR, A.; NAJAFIFAR, A.; SETOODEHMARAM, S. \& MOKHTAR, A. Cephalometry in 14-18 years old girls and boys of Shiraz-Iran high school. Int. J. Morphol., 27(1):101-104, 2009.

boys in this part of country, the present study was done to determine the cephalic index and the types of head shapes in students of South of Iran in Shiraz high school.

\section{MATERIAL AND METHOD}

This study was done on 867 normal girls and 960 normal boys, in Shiraz high school. Shiraz is center of Fars province and located in South of Iran. All the measurements were taken with the person sitting on chair, in relaxed condition and head in anatomical position.

Head measurements, which were determined by Martin spreading caliper, are as follows:

- Head length $=$ Summit of glabella to furthest occipital point. - Head width $=$ Great breadth, at right angles to median plane . - Cephalic index=Maximum head breadth /Maximum head length $\mathrm{x} 100$

Cephalic index were determined on the basis of International Anatomical Descriptive (Williams et al.). Then, the craniofacial typing was determined through comparing this index with the craniofacial phenotypic classification (Table I) and the result was recorded and analysed by statistical formula. The data were subjected to statistical analysis.

Table I. Craniotyping based on the cephalic index.

\begin{tabular}{ll}
\hline Head shape & Cephalic index $\quad$ (CI) \\
\hline Dolichocephalic & $\mathrm{CI}<74.9$ \\
Mesochepalic & $75<\mathrm{CI}<79.9$ \\
Brachycephalic & $80<\mathrm{CI}<84.9$ \\
Hyperbrachycphalic & $85<\mathrm{CI}<89.9$ and $\mathrm{CI}<$ \\
\hline
\end{tabular}

\section{RESULTS}

As the means of head length, width and cephalic index in girls and boys students were shown in Table II, there were significant difference between those of the girls and boys. Head length and width of boys are higher than girls $(\mathrm{P}<0.00)$. Comparision of cephalic index in girls and boys showed significant difference $(\mathrm{P}<0.00)$ (Table II).

Head was classified by cephalic index. Dominant and rare types of head in girls were brachycephalic (42.56\%) and dolichocephalic (4.84\%), respectively (Table III). The boys dominant and rare types were hyperbrachycephalic $(34.3 \%)$ and dolichocephalic (7.5\%), respectively (Table III, Fig. 1).
Table II. Means and SD of head length, head width and cephalic index in girls and boys.

\begin{tabular}{lll}
\hline Measurment & Girls & Boys \\
\hline Head length & $18.20 \pm 0.71$ & $18.45 \pm 0.90$ \\
Head width & $18.76 \pm 0.61$ & $15.17 \pm 0.72$ \\
Cephalic index & $81.20 \pm 4.33$ & $82.40 \pm 5.45$ \\
\hline
\end{tabular}

Table III. The frequency and percentage (\%) of head phenotypes among the 960 boys and 867 girls (14-18 year), in Shiraz -South of Iran.

\begin{tabular}{lcc}
\hline Head shape & Girls & Boys \\
\hline Dolichocephal & 4.84 & 7.5 \\
Mesocephal & 32.76 & 28.4 \\
Brachycephal & 42.56 & 30.0 \\
Hyperbrachcephal & 19.84 & 34.3 \\
\hline Total & 100.0 & 100.0 \\
\hline
\end{tabular}

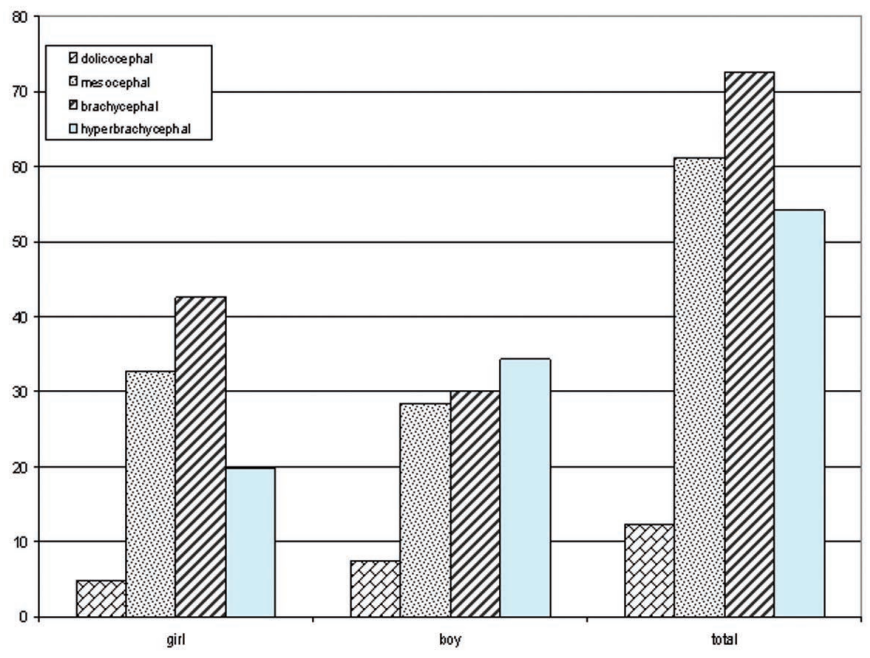

Fig. 1. Distribution of head shape in girls and boys in Shiraz high school.

\section{DISCUSSION}

In this study cephalic index in girls was 81.20. The cephalic index of this study was lower than Nakashima (1986) study on female students with 87, Golalipour (2006a) study on native Fars group with 85 , Turkman group 82.8 in gorgan North of Iran (Golalipour, 2006b), higher than Abolhasanzadeh \& Farahani (2003) study in Tehran- center of Iran with 75, Buretic'-Tomljanovic' et al. (2004) study in Croitia with 79.23 and similar to Shah \& Jadhav report from India with 81.20. 
In our study, the dominant type of head shape in girls was brachycephalic type with $42.5 \%$. It is similar to other study in Tehran center of Iran (42.7\%) (Golalipour, 2006b), Turkman Groups in north of Iran (58.1\%) (Golalipour et al.) and Shah \& Jadhav study in India. But it is different to other study that were done on fars females hyperbrachycephal (53.6\%) (Golalipour, 2006a).

In our study rare type of head in female was dolichocephal $(4.84 \%)$ that was similar to Tehran- Iran (9.9\%) (Abolhasanzadeh \& Farahani), Fars (0.5\%) (Golalipour, 2006a), Turkman in North of Iran $(0.1 \%)$ (Golalipour et al.) and Shah \& Jadhav in India (0.3\%).

In this study, cephalic index in male was 82.4. The cephalic index of this study was higher than the study in Tehran- Iran with 75 (Abolhasanzadeh \& Farahani), Turkman male in north of Iran (Golalipour et al.) and other studies such as India (Shah \& Jadhav) with 80.42, Chile 80.42 (del Sol) and Buretic'-Tomljanovic' et al. study in Croatian with 79.37.

Garcia \& Lips (1986a and 1986b) determined that the cephalic index in Chile is 81.51. The cephalic index reported 81.19 in European people in Mediterranean area and 79.72 in North of Europe.

In our study, dominant type of head shape in male was hyperbrachycephal (34.3\%) and brachycephalic (30\%). This finding is similar to another study was done on Fars males in North of Iran, reported that $52 \%$ of individuals were hyperbrachycephalic, 25\% brachycephalic (Golalipour, 2006a), and another study in Tehran- Iran, reported that $36.6 \%$ of the individuals were brachycephalic, $29.9 \%$ hyperbrachycephalic that it differ from the study in India (Bhatia et al., 1955), which reported the dominant type dolicocephalic (58.5\%), del Sol study in Chile and other study with mesocephalic (Marquer \& Chamela, 1961). In 2004, a study in India on 302 male students showed that $41 \%$ of the students were mesocephalic, $37 \%$ brachycephalic, $14 \%$ heperbrachycephalic, and 7\% dolichocephalic (Shah \& Jadhav).

In our study rare type of head in male was dolichocephal $(7.5 \%)$. It is similar to other studies were done on native Fars males in North of Iran (1.5\%) (Golalipour, 2006a), Tehran-Iran (9\%) (Abolhasanzadeh \& Farahani), but Bathia et al. reported $0.1 \%$ dolichocephal in India.

In conclusion, respect to the variations in head shape in various races and ethnicities and geographical zones, we believe that inhereditary factor primarily affects on the shape of head, however environment has secondary effect on it (Heidari et al., 2006; Golalipour et al.; Golalipour, 2006b). It was noticed that the first generation of Japanese immigrants in Hawaii had an increased head breadth, a decreased head length and a higher cephalic index than their parents (Heravi \& Zieaee, 2002). Time can also induce the gradual expression of genetic characteristics in individual. In a study it was observed that over a period of 30 years, the residents of an area in Japan developed some changes in the form of their cranium toward an increase in the head breadth in the subsequent generation (Nakashima).

With regard to the findings of this study and other investigations in Iran, we can conclude that trend of brachycephalization and hyperbrachycephalization was happened during some centuries on consequents generations of people.

\section{ACKNOWLEDGEMENT}

We appreciate, Vice Chancellor of Shiraz University of Medical Sciences for research grants and Fars Education Administration for their assistance.

VOJDANI, Z.; BAHMANPOUR, S.; MOMENI, S.; VASAGHI, A.; YAZDIZADEH, A.; KARAMIFAR, A.; NAJAFIFAR, A.; SETOODEHMARAM, S. \& MOKHTAR, A.Cefalometría en niñas y niños de 14-18 años de la secundaria de Shiraz, Irán. Int. J. Morphol., 27(1):101-104, 2009.

RESUMEN: La cefalometría o medición del cráneo se utiliza en pediatría, medicina forense, cirugía plástica, cirugía oral, diagnóstico del paciente y el entendimiento de las poblaciones normales. El índice cefálico es un parámetro importante para la detección de la raza y el sexo de una persona cuya identidad se desconoce. Las dimensiones cefalométricas más importantes son la altura y peso de la cabeza que determinan el índice cefálico. En base al índice cefálico cuatro formas de la cabeza son clasificadas en categorías internacionales: dolicocefálica, braquicefálica, mesocefálica e hiperbraquicefálica. Debido a la falta de información sobre las niñas y niños de 14-18 años, en este ámbito, se planificó el presente estudio para la determinar el rango normal de la forma de la cabeza, en 867 niñas y 960 niños, de 14 a18 años de edad en Fars, Irán. Los resultados mostraron que el tipo dominante de cabeza en las niñas fue braquicefálico $(42,5 \%)$ y en niños fue hiperbraquicefálico (34,3\%). El tipo de cabeza de forma dolicocefálico en niñas en un $4,80 \%$ y en niños en el 7,5\%. Existen diferencias significativas entre el índice cefálico de niños y niñas. 
VOJDANI, Z.; BAHMANPOUR, S.; MOMENI, S.; VASAGHI, A.; YAZDIZADEH, A.; KARAMIFAR, A.; NAJAFIFAR, A.; SETOODEHMARAM, S. \& MOKHTAR, A. Cephalometry in 14-18 years old girls and boys of Shiraz-Iran high school. Int. J. Morphol., 27(1):101-104, 2009.

\section{REFERENCES}

Abolhasanzadeh, A. \& Farahani, M.R. Standarded international classification of head shapes of 22-24 years old in Tehran. J. of Research in medicine, 26(4):281-5, 2003.

Buretic'-Tomljanovic', A.; Ristic', S.; Brajenovic'-Milic', B.; Ostojic', S.; Gombac, E. \& Kapovic', M. Secular change in body height and cephalic index of Croatian medical students (University of Rijeka). Am. J. Phys. Anthropol., 123(1):91-6, 2004.

Bhatia, M.; Thin, J.; Debray, H. \& Cabanes, J. Etude anthropologique et genetique de la population du Nord de l'Inde. Bull. Et Mem Soc. d'anthrop. de Paris, 10(6):199-213,1955.

Del sol, M. Cephalic index in a group of mapuche individuals in the IX Region of Chile. Int. J. Morphol., 23(3):241-6, 2005 .

Eickstedt, E. V. The races and types of the western Himalayas. Man in India, 6:237, 1926.

García, H. F. \& Lips, M. W. Contribución al estudio del índice cefálico en chilenos. An. Anat. Normal, 4:1203,1986a.

García, H. F. \& Lips, M.W. Variaciones del índice cefálico en chilenos según ascendencia. An. Anat. Normal, 4:1179, 1986b.

Golalipour, M. J. The variation of head shapes in 17-20 years old native Fars male in Gorgan-North of Iran. Int. J. Morphol., 24(2):187-90, 2006 a.

Golalipour, M. J. The effect of ethnic factor on cephalic Index in 17-20 years old females of North of Iran. Int. J. Morphol., 24(3):319-22, 2006 b.

Golalipour, M. J.; Jahanshahi, M. \& Haidari, K. Morphological evaluation of head in Turkman males in Gorgan-North of Iran. Int. J. Morphol., 25(1):99-102, 2007.

Grant, T. M. \& Peter, A. M. Size and shape measurement in contemporary cephalimeyrics. Eur. J. of orthodontics. 25(3):231-42, 2003.

Grau, V.; Alcaniz, M.; Juan, M. C.; Monserrat, C. \& Knoll, C. Automatic localization of cephalometric landmarks. J. of Biomedical Informatics, 34:146-56, 2001.
Heidari, Z.; Mahmoudzadeh Sagheb, H. R. \& Noori Mugahi, M. H. Morphological evaluation of head and face in 1825 years old women in Southeast of Iran. J. Med. Sci., 6:400-4, 2006.

Heravi, F. \& Zieaee, H. Assessing the importance of cephalic and facial indices in a group of 12 years old boys in Mashhad. Beheshti Univ. Dent. J., 20:119-24, 2002.

Marquer, P. \& Chamela, M. C. L'evolution des caracteres morphologiques en function de l'age, chez 2089 fracais, de 20 a 91 ans. Bull. et Mem. Soc. d'Anthrop. de Paris, 11:1-78, 1961 .

Nakashima, T. Brachycephalization in the head form of school girls in north kyuoshu. Sangyo. Ika Dainguku Zussshi. 8(4):411-4, 1986.

Shah, G. V. \& Jadhav, H. R. The study of cephalic index in students of Gujarat. J. Anat. Soc. India, 53(1):25-6, 2004.

Thurston, E. Castes and Tribes of Southern India. Madras, Government Press, 1909.

Williams, P.; Dyson, M.; Dussak, J. E.; Bannister, L. H.; Berry, M. M.; Collins, P. \& Ferguson, M. W. J. Gray's Anatomy. $38^{\text {th }}$ Ed. Elbs with Churchill Livingston, London, 1995. pp. 607-12.

Correspondence to:

Zahra Vojdani

Assistant Professor

Department of Anatomy

Shiraz University of Medical Sciences

Shiraz, Iran

Tel: ++98 07112304372

Fax : ++98 07112304372

E mail: vojdaniz@sums.ac.ir

Received: 15-06-2008

Accepted: 22-10-2008 